\title{
Perception of Social Security by the Employees \\ of a Large Industrial Enterprise \\ from the Perspective of Post-Nonclassical Sociology
}

\author{
Anna P. Kareeva* \\ Siberian Federal University \\ 79 Svobodny, Krasnoyarsk, 660041, Russia
}

Received 06.05.2015, received in revised form 16.06.2015, accepted 21.08.2015

The article analyzes the employees' perception of social security established on a large industrial enterprise. The following methods were applied: the questionnaire survey method, the method of factor and correlation analysis. They have revealed the employees' attitude to the concepts of "social security", "social policy", their interest in improving social security at the enterprise. Factor analysis made it possible to identify the "most important" indicators of social security as well as the extent of their implementation at the enterprise. The "least and poorly implemented" indicators show that social security hardly satisfies the employees who perceive it as insufficient to protect themselves against social risks at the enterprise.

Keywords: industrial enterprise, social security, social risks, the questionnaire survey method, parameters and indicators of social security, factor and correlation analysis.

DOI: 10.17516/1997-1370-2015-8-9-1886-1892.

Research area: sociology.

The term of "social security" is relatively new in science. V.N. Kelas'ev (Kelas'ev 1999) believes that inattention to a human, neglect of his / her interests and needs have always been peculiar for Russia. In Soviet times social security was identified with national security. Rethinking of this term takes place in the 90s. It was caused by social threats to the country's population.

Today sociologists consider social security from different points of view. Thus, V.N. Kuznetsov (Kuznetsov 2007) considers it an integral part of national security, D.V. Zerkalov
(Zerkalov 2012), R.G. Ianovskii (Ianovskii 1999) and other scholars use the term "social security" to refer to the security of the entire complex of different threats to the population, the threats being not only social but also economic, environmental, etc. V.K. Levashov (Levashov 2002) considers this category in the light of globalization.

The process of capitalism development, in the course of which economic and social spheres were separated, served the impulse for the research of social security. Social security is an integral part in the modern society of risk and holds a leading position in it. As for globalization,

(c) Siberian Federal University. All rights reserved

* Corresponding author E-mail address: karenina3010@rambler.ru 
it reinforces the role of social security in society. Social security is peculiar for all spheres of society. Its aim is to "soften, smooth, eliminate the social evils peculiar for our communities nowadays" (Koptseva 2014). Its object and subject is a human. It is he / she whose main demand is to reduce social tension and make his / her life relatively stable, the guarantor of social security being the social policy of the state.

Social security is also peculiar for a modern industrial enterprise. It is its integral part. It holds one of leading places, permeates all spheres of working life and aims at the reduction or complete neutralization of social risks at an enterprise. The social policy of the enterprise is a guarantor of social security. If the social policy completely or partially satisfies the employees' needs, the social security will be high and vice versa.

The object of our research is social security established at a large industrial enterprise, its subject is the employees' perception of social security at this enterprise. The largest industrial enterprise under the research is the mining and chemical plant located in the city of Zheleznogorsk, Krasnoyarsk Krai.

It has been hypothesized that this mining and chemical plant minimized the social risks, which it faced through the course of its activities, through the social security and namely through the social policy as its manifestation. At that the perception of social security by the employees of the plant directly depends on the implementation of the social security measures.

The method applied is the questionnaire survey one, the form of the survey is the group questionnaire. In order to carry out a detailed analysis of social security of the enterprise all the parameters were divided into twenty-two indicators.

1. Economic well-being (material remuneration of the employee, social package from the company).
2. Personal safety (conditions for the employees' quality performance of their work, safety, the employees' understanding of production goals, results of their labor, their importance for the enterprise).

3. Professional growth (ability of the employees' professional growth at the enterprise).

4. Production infrastructure (control of environmental conditions at the enterprise and in the area of the employees' residence, keeping the balance between work and personal time, observance of sanitaryhygienic and aesthetic conditions of work at the enterprise, catering, transport and health services at the enterprise).

5. Social stability (relationships with colleagues and immediate supervisors, top managers and administration, the employees' confidence in the future, their awareness of the company's prospects, recognition of the employees' labour achievements, the employees' timely material and moral encouragement (bonuses) by the enterprise, factory administration).

6. Social infrastructure (the employees' housing and living conditions, organization of corporate leisure).

7. Creative initiative (displaying of creative initiative by the employees).

8. The employees' participation in the production management (exchange of the employees' views on industrial matters, the employees' involvement in the production management).

A survey at the mining and chemical plant took place from November to December 2013. The author of the article and volunteers took part in it. The results were analyzed with SPSS Statistics 20.0 software. Pearson correlation method was used to find pairwise correlations between the elements under the research, Varimax method was used for factor analysis. 
The results were interpreted within the frame of the universum sociological paradigm (Nemirovskii 1999, 2004; Nemirovskii, Kudriavtseva 2003). This paradigm comprises all the main features of the post-nonclassical stage of sociology development. It is based on the methodological principle of minimum universum which is a matrix for the process of the system development. The principle includes two elements, three levels, five conditions, seven layers, twelve qualities.

In this article a large industrial enterprise is viewed as a disassembled protosystem. The minimum universum position considers social security and social danger to be its two polar elements. In the current situation both elements are peculiar for each industrial enterprise. Their correlation largely depends on the social policy at the enterprise as well as on the employees' perception of the enterprise as socially safe or socially dangerous.

According to the principle of minimum universum each developing system forms three levels in the process of its change: materialand-energy, functional-and-organizational, informational. The indicators of social security, which we have singled out, were attributed to them. Economic welfare, industrial and social infrastructure and personal safety were assigned to the material-and-energy level. Social stability was assigned to the functionaland-organizational level. The third level, which is the informational one, is represented by three indicators of social security. These are the employees' professional growth, their participation in the production management, and creative initiative.

The following results were obtained during the analysis.

The term "social security" is not familiar to the employees of the mining and chemical plant. The usual term for them is that of "social policy of the enterprise". This term is known to $89 \%$ of the respondents, $82 \%$ of them use it.

Most of the participants finished the sentence "The social policy of the enterprise is ..." the following way: "The Social policy of the enterprise is a social activity aimed at the protection of its employees". According to them, considerable attention should be given to social benefits, guarantees and working conditions of the employees.

Over $76 \%$ of the respondents are "satisfied" with the existing social policy at the enterprise. $17 \%$ of them say that their satisfaction is "complete", $59 \%$ of the respondents are "partially" satisfied. There are also dissatisfied respondents. Their number is $23 \%$. Those who are "partially dissatisfied" with the current social policy dominate among them. Only $5 \%$ of the total number of the respondents is "completely dissatisfied".

On average, $71 \%$ of the employees "want to make occasional changes" in the current social policy at the enterprise. Such employees are also numerous at the radiochemical (80\%) and isotopic-chemical (72\%) plants. The percentage of the respondents who believe the social policy at the enterprise to be good is $27 \%$. The highest percentage of such employees is peculiar for the reactor plant (42\%).

Two positions regarding the willingness of the staff to participate in the activities aimed at improving social policy dominate at the enterprise. The position of "being ready" is shared by $56 \%$ of the respondents, the position of "being not ready" is shared by $44 \%$ of the respondents.

The employees consider that the mining and chemical plant faces social risks at present. Three groups of social risks are most obvious. These are the risks of reducing social stability of the enterprise, the risks of reducing economic wellbeing and personal safety. 
Correlation analysis of "the implemented indicator of social safety - satisfied with social policy" variables shows that fourteen indicators out of twenty-two influence the social policy of the enterprise. The employees' satisfaction with the social policy of the enterprise and, consequently, with the social security depends on the employees' satisfaction with the implementation of these indicators as the social security at the enterprise is implemented through its social policy.

Factor analysis confirmed that the employees consider these fourteen indicators to be "the most important" for themselves. All fourteen indicators were concentrated in one factor group. The percentage of variance in this group is $40,3 \%$. Using correlation coefficients, we have worked out a hierarchy of indicators of social security at the enterprise.

The first place is taken with the indicators with a correlation coefficient of 0,7 :

1. The employees' timely material and moral encouragement (bonuses) by the enterprise, factory administration.

2. The employees' understanding of production goals.

3. Conditions for the employees' quality performance of their work.

The second place is taken with the indicators with a correlation coefficient of 0,6 :

1. Recognition of the employees' labour achievements.

2. Exchange of the employees' views on industrial matters.

3. The employees' involvement in the production management.

4. Safety.

5. The employees' understanding of their labor results, importance for the enterprise.

6. The employees' confidence in the future.

The third place is taken with the indicators with a correlation coefficient of 0,5 :
1. Observanceofsanitary-hygienicandaesthetic conditions of work at the enterprise.

2. Deserved material remuneration.

3. Keeping the balance between work and personal time.

4. The employees' professional growth at the enterprise.

The fourth place is taken with the "social package of the enterprise" indicator with a correlation coefficient of 0,4 .

Based on the obtained results, it can be argued that the better these indicators are implemented in the current social policy of the enterprise the better the employees perceive social security existing at it.

"The most important" indicators were subjected to factor analysis again, its aim being the need to identify the degree of implementation of each indicator at the mining and chemical plant. On a result of factor analysis all the indicators were grouped into four factor groups. The same percentage of variance (from $14 \%$ to $11 \%$ ) was revealed for each group.

Table 1 shows that the first factor group comprises the indicators which are the "least implemented" at the mining and chemical plant. The second factor group includes "poorly implemented" indicators with the percentage of implementation varying from $30 \%$ to $40 \%$. The third factor group consists of five indicators which are "well implemented" at the plant. The fourth factor group includes the "most implemented" indicators. Percentage of their implementation ranges from $50 \%$ and up.

Basing on factor analysis, we conclude that the "most important" indicators are not equally implemented at the enterprise. On average, only $50 \%$ of indicators are "sufficiently implemented", the rest are "poorly implemented".

The "least and poorly implemented" indicators suggest that the current social policy meets the employees' needs insufficiently. In turn, the 
Table 1. Distribution of important indicators of social security according to factor groups and percentage of their implementation at the mining and chemical plant ( \%)

\begin{tabular}{|c|c|c|}
\hline № & Indicators & $\begin{array}{l}\text { Percentage of their } \\
\text { implementation at the mining } \\
\text { and chemical plant }\end{array}$ \\
\hline \multicolumn{3}{|c|}{ Factor group I } \\
\hline 1 & Material remuneration of the employee & $23 \%$ \\
\hline 2 & Conditions for the employees' quality performance of their work & $26 \%$ \\
\hline 3 & The employees' confidence in the future & $27 \%$ \\
\hline 4 & Recognition of the employees' labour achievements & $29 \%$ \\
\hline \multicolumn{3}{|c|}{ Factor group II } \\
\hline 1 & $\begin{array}{l}\text { The employees' timely material and moral encouragement } \\
\text { (bonuses) by the enterprise administration }\end{array}$ & $30 \%$ \\
\hline 2 & Exchange of views on industrial matters & $39 \%$ \\
\hline \multicolumn{3}{|c|}{ Factor group III } \\
\hline 1 & The employees' involvement in the production management & $45 \%$ \\
\hline 2 & $\begin{array}{l}\text { Observance of sanitary-hygienic and aesthetic conditions of work at } \\
\text { the enterprise }\end{array}$ & $43 \%$ \\
\hline 3 & Keeping the balance between work and personal time & $40 \%$ \\
\hline 4 & $\begin{array}{l}\text { The employees' understanding of their labor results, importance for } \\
\text { the enterprise }\end{array}$ & $48 \%$ \\
\hline 5 & The employees' professional growth & $49 \%$ \\
\hline \multicolumn{3}{|c|}{ Factor group IV } \\
\hline 1 & The employees' understanding of production goals & $54 \%$ \\
\hline 2 & Safety & $68 \%$ \\
\hline 3 & Social package & $64 \%$ \\
\hline
\end{tabular}

social policy, that poorly satisfies the employees, reduces the social security of the enterprise as it is implemented through its social policy. The employees perceive it as insufficient to protect themselves against social risks at the enterprise.

The "least and poorly implemented" indicators refer to 4 indicators of social security. These are social stability, personal safety, economic well-being and the employee's participation in the production management. A particularly big gap is observed in the "social stability" indicator. According to the principle of minimum universum, this indicator refers to the functional-and-organizational level.
"Poorly implemented" indicators at the enterprise directly influence the employees' perception of social security. The greater the number of "poorly implemented" indicators at the enterprise is the worse the employees' perception of its social policy and thus its social security is. This also proves the conclusion that three groups of social risks are the most obvious at the enterprise. These are the risks of reducing social stability of the enterprise, the risks of reducing economic well-being and personal safety. The employees are mostly worried with the risks of reducing social stability of the enterprise. 


\section{References}

1. Ianovskii R.G. Global'nye izmeneniia i sotsial'naia bezopasnost' [Global changes and social security]. Moscow: Academia, 1999.

2. Kelas'ev V.N. (1999). Sotsial'naia zashchita naseleniia i vlast' [Social protection of the population and the authorities]. The journal of sociology and social anthropology, II (2), 80-89.

3. Koptseva N.P. (2012). Kul'turologicheskaia baza formirovaniia obshchenatsional'noi rossiiskoi identichnosti v sibirskikh regionakh Rossiiskoi Federatsii [Cultorological base of formation of national Russian identity in the Siberian regions of the Russian Federation]. Science journal of Volgograd State University. Series 7: Philosophy, 3(18), 11-15.

4. Koptseva N.P. (2014). K voprosu o kontseptual'nykh osnovaniiakh stroitel'stva obshchenatsional'nogo rossiiskogo gosudarstva [On the issue of conceptual grounds of the construction of the Russian national state]. Problemy politiki i obshchestva, 1, 1-14.

5. Kuznetsov V.N. Sotsiologiia bezopasnosti [Sociology of security]. Moscow, 2007. 423 p.

6. Levashov V.K. (2002). Globalizatsiia i ustoichivoe razvitie [Globalization and sustainable development]. Nauka i praktika, 1, 19-38.

7. Nemirovskii V.G. Vvedenie $v$ teoreticheskuiu sotsiologiiu [Introduction to theoretical sociology]. Krasnoyarsk, Krasnoyarsk State University, 1991. 122 p.

8. Nemirovskii V.G. Osnovy teoreticheskoi sotsiologii [Basics of theoretical sociology]. Krasnoyarsk, Krasnoyarsk State University, 1994. 133 p.

9. Nemirovskii V.G. Sovremennaia teoreticheskaia sotsiologiia [Modern theoretical sociology]. Krasnoyarsk, Krasnoyarsk State University, 2003. 303 p.

10. Nemirovskii V.G. (2004). Universumnaia paradigma sovremennoi rossiiskoi sotsiologii kak perspektiva razvitiia [Universum paradigm of contemporary Russian sociology as a developmental perspective]. Sotsiologiia. Nauchno-teoreticheskii zhurnal, 1, 39-49.

11. Nemirovskii V.G., Grishaev S.V. (1999). Sotsial'nyi portret molodogo predprinimatelia [Social portrait of a young entrepreneur]. Sociological studies, 5, 40-43.

12. Nemirovskii V.G., Kudriavtseva V.I. Universumnyi podkhod $k$ dinamike sotsial'nykh system:

analiz $i$ prognozirovanie [Universum approach to the dynamics of social systems: analysis and forecasting]. Krasnoyarsk, Minsk, 2003. Pp. 65-77.

13. Zerkalov D.V. Sotsial'naia bezopasnost' [Social security]. Kiev: Osnova, 2012. 530 p. 


\title{
Восприятие социальной безопасности \\ сотрудниками крупного промышленного предприятия \\ с позиции постнеклассической социологии
}

\author{
А.П. Кареева \\ Сибирский федеральный университет \\ Россия, 660041, Красноярск, пр. Свободный, 79
}

\begin{abstract}
В статье проанализировано восприятие сотрудниками крупного промышленного предприятия социальной безопасности, сложившейся на нем. Использованы следующие методы: метод анкетного опроса, метод факторного и корреляционного анализа. Выявлено отнотение сотрудников предприятия к понятиям «социальная безопасность», «социальная политика», их заинтересованность в улучшении сочиальной безопасности, которая уже сложилась на предприятии. Факторный анализ позволил выделить «наиболее важные» индикаторы социальной безопасности, а также степень их реализации на предприятии. Наличие «наименее и слабо реализуемых» индикаторов свидетельствует о том, что сочиальная безопасность недостаточно устраивает работников. Сотрудники предприятия воспринимают ее как недостаточную для защиты себя от сочиальных рисков, возникающих на предприятии.
\end{abstract}

Ключевые слова: промышленное предприятие, сочиальная безопасность, социальные риски, метод анкетного опроса, показатели и индикаторы социальной безопасности, факторный и корреляиионный анализ.

Научная специиальность: 22.00.00 - социологические науки. 